.. Ayrilmis, Kariz, Kwon, Kuzman: Surface Roughness and Wettability of Surface Densified...

\title{
Surface Roughness and Wettability of Surface Densified Heat-Treated Norway Spruce (Picea abies L. Karst.)
}

\section{Hrapavost i stupanj kvašenja ugušćene površine pregrijane smrekovine (Picea abies L. Karst.)}

\author{
Original scientific paper • Izvorni znanstveni rad \\ Received-prispjelo: 3. 12. 2018. \\ Accepted-prihvaćeno: 20. 11. 2019. \\ UDK: $630 * 827.4 ; 630 * 812.24$ \\ https://doi.org/10.5552/drvind.2019.1852
}

\begin{abstract}
Surface roughness and wettability of the heat-treated and then surface densified spruce (Picea abies L. Karst.) wood were measured to determine the effect of densification and heat-treatment on wood surface properties. The process of heat-treatment with an initial vacuum was performed in a vacuum chamber on oven dried lamellas with dimensions of $630 \mathrm{~mm}$ (longitudinal direction) $x 45 \mathrm{~mm}$ (tangential direction) $x 25 \mathrm{~mm}$ (radial direction). The lamellas were heat-treated at four different temperatures which were $170{ }^{\circ} \mathrm{C}, 190{ }^{\circ} \mathrm{C}, 210^{\circ} \mathrm{C}$ and $230^{\circ} \mathrm{C}$. Control specimens were not exposed to heat-treatment. The lamellas were first heated to $100^{\circ} \mathrm{C}$, the creation of a vacuum taking $30 \mathrm{~min}$ at this temperature, and then heated to the desired temperature, and treated at this constant temperature for $3 \mathrm{~h}$. The lamellas were then cooled down by using coils with cold water inside the chamber. Surface densification of lamellas with compression from $22 \mathrm{~mm}$ to $15 \mathrm{~mm}$ thickness was made by press platens heated at $150{ }^{\circ} \mathrm{C}$ and held in that position for $60 \mathrm{~s}$. After the $1 \mathrm{~min}$, the heated platen was cooled to 90 ${ }^{\circ} \mathrm{C}$, whilst the specimen remained under compression to minimize immediate spring back. The total time of compression was $2 \mathrm{~min}$ (30 s closing, $60 \mathrm{~s}$ pressing and approx. $30 \mathrm{~s}$ cooling). In the treatment groups, the optimum treatment temperature on the one-side densified wood specimens was found to be $170{ }^{\circ} \mathrm{C}$ based on the surface roughness and wettability values. Surface densification significantly decreased the surface roughness of the wood specimens. The surface quality of wood can be improved when the wood is exposed to the heat-treatment and then surface densification.
\end{abstract}

Keywords: heat-treatment, wood, surface roughness, wettability, densification

SAŽETAK • Cilj istraživanja bio je izmjeriti hrapavost $i$ stupanj kvašenja površine pregrijane i površinski ugušćene smrekovine (Picea abies L. Karst.) kako bi se utvrdio utjecaj ugušćivanja i pregrijavanja na svojstva po-

\footnotetext{
${ }^{1}$ Authors is professor at Istanbul University-Cerrahpasa, Forestry Faculty, Department of Wood Mechanics and Technology, Istanbul, Turkey. ${ }^{2}$ Authors are assistant professor and associate professor at University of Ljubljana, Biotechnical Faculty, Department of Wood Science and Technology, Ljubljana, Slovenia. ${ }^{3}$ Authors is professor at National Institute of Forest Science, Department of Forest Products, Seoul, Republic of Korea.

Autor je profesor Istanbulskog sveučilišta-Cerrahpasa, Šumarski fakultet, Zavod za mehaniku drva i tehnologiju, Istanbul, Turska. ${ }^{2}$ Autori su docent i izvanredni profesor Sveučilišta u Ljubljani, Biotehnički fakultet, Zavod za znanost o drvu i tehnologiju, Ljubljana, Slovenija. ${ }^{3}$ Autor je profesor Nacionalnog instituta šumarske znanosti, Zavod za šumarske proizvode, Seul, Republika Koreja.
} 
vršine drva. Proces pregrijavanja s početnim vakuumom proveden je u vakuumskoj komori na apsolutno suhim lamelama dimenzija $630 \mathrm{~mm}$ (uzdužni smjer) $\times 45 \mathrm{~mm}$ (tangentni smjer) $\times 25 \mathrm{~mm}$ (radijalni smjer). Lamele su pregrijane na četiri različite temperature: $170{ }^{\circ} \mathrm{C}, 190^{\circ} \mathrm{C}, 210^{\circ} \mathrm{C}$ i $230^{\circ} \mathrm{C}$. Kontrolni uzorci nisu bili pregrijani. Lamele su najprije zagrijane na $100^{\circ} \mathrm{C}$ i pri toj je temperaturi za postizanje vakuuma bilo potrebno 30 min. Uzorci su nakon toga zagrijani na željenu temperaturu koja je konstantno održavana tri sata. Potom su lamele ohlađene uz pomoć hladne vode koja se nalazila u spiralnim cijevima unutar komore. Ugušćivanje površine lamela s $22 \mathrm{~mm}$ na $15 \mathrm{~mm}$ debljine provedeno je prešanjem zagrijanim pločama na temperaturi $150{ }^{\circ} \mathrm{C}$ u trajanju $60 \mathrm{~s}$. Nakon jedne minute zagrijana je ploča ohlađena na $90{ }^{\circ} \mathrm{C}$, dok je uzorak ostao pod pritiskom kako bi se umanjio trenutačni povrat. Ukupno vrijeme prešanja iznosilo je 2 min (30 s zatvaranje, 60 s prešanje i oko 30 s hlađenje). Na temelju vrijednosti hrapavosti i stupnja kvašenja utvrđeno je da je optimalna temperatura za jednostrano ugušćivanje ploče $170{ }^{\circ}$ C. Ugušćivanjem površine znatno se smanjila hrapavost površine uzoraka drva. Zaključeno je da se kvaliteta površine drva može poboljšati pregrijavanjem i ugušćivanjem površine.

Ključne riječi: pregrijavanje, drvo, hrapavost površine, stupanj kvašenja, ugušćivanje

\section{INTRODUCTION}

\section{UVOD}

Heat-treatment is one of the most environmentally friendly methods to improve decay resistance and dimension stabilization of wood (Hill, 2006; Sinković et al., 2011; Govorčin et al., 2011). Heat-treatment is an effective method to improve some properties of wood such as biological durability and dimensional stability in changing environments. Heat-treatment changes the chemical composition of wood, which mainly results in the degradation of the hemicelluloses, carbohydrate cleavage, reduction in the degree of polymerization of the carbohydrates (Tjeerdsma et al., 1998; Kariz et al., 2017; Lunguleasa et al., 2018).

Densification of wood is an effective way for modifying low density tree species to make them comparable with higher density tree species. Furthermore, densification is a way of utilizing low-density wood species instead of high density species in applications of higher value (Kariz et al., 2017). The mechanical properties and dimensional stability of low-density wood can be improved by the heat-treatment in modification chamber followed by densification process (Kwon et al., 2014). This will give a significant advantage to the densified wood for structural applications, which require stiffness, hardness, strength in building industry. Furthermore, heat-treatment and surface densification can open new markets for the lumber companies that use low density tree species such as pine, spruce, and fir.

Surface roughness and wettability are two important parameters that affect the surface quality of wood, in particular for paint and varnish, glue applications or use as floorings. There are different techniques to measure surface roughness of wood such as laser, acoustic emission, pneumatic, and stylus. The stylus technique is commonly used to quantify surface roughness of wood and wood-based composites. In the stylus technique, standard numerical parameter, such as average roughness $\left(R_{\mathrm{a}}\right)$ and the maximum height of profile, is the sum of the largest peak height and the largest valley depth within a sampling length $\left(R_{\mathrm{z}}\right)$, and the root mean square deviation of the profile $\left(R_{\mathrm{q}}\right)$ is used to evaluate surface roughness of the material (ISO 4287:1997/Amd.1, 2009).

This study was a progressive part of the joint research work between University of Ljubljana Biotech- nical Faculty and Forestry Faculty of Istanbul University. The aim of this study was to understand the effect of heat-treatment and then surface densification process on the surface properties of Norway spruce wood.

\section{MATERIALS AND METHODS} 2. MATERIJALI I METODE

\subsection{Heat-treatment of wood specimens}

2.1. Pregrijavanje uzoraka drva

Norway spruce (Picea abies L. Karst) wood lamellae with dimensions of $630 \mathrm{~mm}$ (longitudinal direction $) \times 45 \mathrm{~mm}($ tangential direction $) \times 25 \mathrm{~mm}$ (radial direction) were heat-treated at increasing temperatures $\left(170,190,210\right.$ or $\left.230^{\circ} \mathrm{C}\right)$ with the process having initial vacuum phase. The treatment process started with heating the lamellae to $100{ }^{\circ} \mathrm{C}$ and stabilization at this temperature, followed by a vacuum phase, when air was removed from the modification chamber. The chamber was then heated to the desired modification temperature $\left(170,190,210\right.$ or $\left.230^{\circ} \mathrm{C}\right)$ and wood was treated at this temperature for $3 \mathrm{~h}$ and finally cooled to room temperature. Prior to surface densification, the conditioned lamellas were cut into specimens having dimensions of $150 \mathrm{~mm}$ (longitudinal direction), $43 \mathrm{~mm}$ (tangential direction) and thickness of $22 \mathrm{~mm}$ (radial direction). Ten specimens were used for each treatment type.

\subsection{Densification of wood specimens}

2.2. Ugušćivanje uzoraka drva

The one-side surface of the heat-treated wood specimens was densified using a specially designed hot-press fitted to a universal testing machine (Model: Zwick 1475). The specimens with the initial thickness of $22 \mathrm{~mm}$ were compressed in the radial direction (tangential surface) to the target thickness of $15 \mathrm{~mm}$. The press platens consisted of upper unheated platen and bottom heated/cooled platen. The press platen was heated with electric heater inside the metal platen and cooled with cold water flow through the platen. Each specimen was attached to the unheated press platen. The press was then closed to the target thickness of 15 $\mathrm{mm}$. The specimens were pressed on the platen heated at $150{ }^{\circ} \mathrm{C}$ and held in that position for $60 \mathrm{~s}$. After the 1 min, the heated platen was cooled to $90{ }^{\circ} \mathrm{C}$, whilst the specimen remained under compression to minimize immediate springback. The total time of compression 
Table 1 Density, weight loss, and equilibrium moisture content of heat-treated wood specimens at different temperatures (Kariz et al., 2017)

Tablica 1. Gustoća, gubitak mase i ravnotežni sadržaj vode pregrijanih uzoraka drva pri različitim temperaturama (Kariz et al., 2017.)

\begin{tabular}{|c|c|c|c|}
\hline $\begin{array}{c}\text { Temperature, }{ }^{\circ} \mathbf{C} \\
\text { Temperatura },{ }^{\circ} \mathrm{C}\end{array}$ & $\begin{array}{c}\text { Average density, } \mathbf{k g} / \mathbf{m}^{3} \\
\text { Srednja gustoća, } \mathrm{kg} / \mathrm{m}^{3}\end{array}$ & $\begin{array}{c}\text { Weight loss, \% } \\
\text { Gubitak mase, \% }\end{array}$ & $\begin{array}{c}\text { Equilibrium moisture content (EMC), \% } \\
\text { Ravnotežni sadržaj vode (EMC), \% }\end{array}$ \\
\hline $\begin{array}{c}\text { Untreated control group } \\
\text { Netretirani kontrolni uzorci }\end{array}$ & $436(35)$ & - & $10.9(0.4)$ \\
\hline 170 & $424(12)$ & $1.370 .08)$ & $7.7(0.4)$ \\
\hline 190 & $412(20)$ & $2.590 .18)$ & $7.3(0.4)$ \\
\hline 210 & $417(17)$ & $4.790 .34)$ & $6.0(0.3)$ \\
\hline 230 & $390(19)$ & $9.670 .85)$ & $4.8(0.5)$ \\
\hline
\end{tabular}

*The values in the parenthesis are standard deviations. / Vrijednosti u zagradama standardne su devijacije.

was $2 \mathrm{~min}(30 \mathrm{~s}$ closing, $60 \mathrm{~s}$ pressing and approx. $30 \mathrm{~s}$ cooling). The densification of wood occurred only on the side in contact with the heated platen (Figure 1). The surface roughness and wettability measurements were performed on the surface exposed to the hot platen during the densification. Before the experiments, the treated lamellae were conditioned in a climate room with relative humidity of $65 \%$ and temperature of $20^{\circ} \mathrm{C}$ until a constant mass.

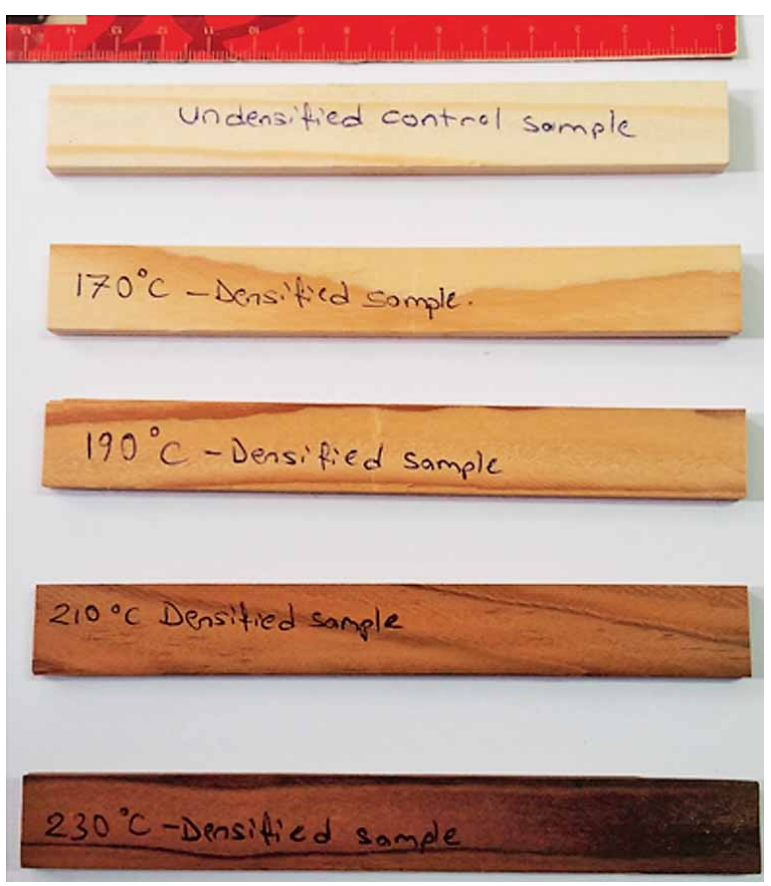

Figure 1 Undensified control specimen and heat-treated/ densified specimens

Slika 1. Kontrolni neugušćeni uzorci i pregrijani/ugušćeni uzorci

\subsection{Determination of surface roughness of wood specimens}

2.3. Određivanje hrapavosti površine uzoraka drva

The stylus method was used to measure the surface roughness of the control and treated wood specimens. Ten specimens were used for each treatment temperature and densification level. A total of forty measurements with a $15 \mathrm{~mm}$ tracing length, 2 measurements parallel and 2 measurements perpendicular to the fibers of each wood specimen (10 specimens for each treatment group and control group) were taken using a stylus profilometer (Mitutoyo SJ-301, Japan). Three surface roughness parameters $\left(R_{\mathrm{a}}, R_{\mathrm{z}}, R_{\mathrm{q}}\right)$, specified in ISO 4287:1997/Amd.1:2009 standard, were used to evaluate the surface characteristics of the specimens. The average values and standard deviations of three roughness parameters were calculated for each treatment group. The tracing line $\left(L_{\mathrm{t}}\right)$ and the cut-off were $15 \mathrm{~mm}$ and $\lambda=2.5 \mathrm{~mm}$, respectively.

\subsection{Determination of wettability of wood specimens}

2.4. Određivanje stupnja kvašenja uzoraka drva

The wettability of the specimens was determined by contact angle technique. The contact angle technique reveals significant findings to understand the surface absorption and coating properties of wood and wood-based composites (Kajita and Skaar, 1992). As the contact angle value of the water droplet is lower than $90^{\circ}$, the solid surface has hydrophilic property and, when the contact angle is higher than $90^{\circ}$, the solid surface has hydrophobic property. A distilled water droplet $(5-\mu \mathrm{L})$ was applied to the wood surface using a plastic pipette. The contact angle was then measured by a digital camera KSV CAM 101 (KSV

Table 2 Densities of top and bottom surfaces of heat-treated and then densified spruce"wood specimens (Kariz et al., 2017)

Tablica 2. Gustoće gornje i donje strane površine pregrijanih i ugušćenih uzoraka smrekovine (Kariz et al., 2017.)

\begin{tabular}{|c|c|c|}
\hline $\begin{array}{c}\text { Heat-treatment temperature, }{ }^{\circ} \mathbf{C} \\
\text { Temperatura pregrijavanja, }{ }^{\circ} \mathrm{C}\end{array}$ & $\begin{array}{c}\text { Density of surface } \\
\text { (hot platen side), } \mathbf{~ k g} / \mathbf{m}^{3} \\
\text { Gustoća površine } \\
\text { (vruća strana ploče), } \mathrm{kg} / \mathrm{m}^{3}\end{array}$ & $\begin{array}{c}\text { Density of surface } \\
\text { (cold platen side), } \mathbf{k g} / \mathbf{m}^{3} \\
\text { Gustoća površine } \\
\text { (hladna strana ploče), } \mathrm{kg} / \mathrm{m}^{3}\end{array}$ \\
\hline 170 & $737(61)$ & $405(75)$ \\
\hline 190 & $624(66)$ & $469(62)$ \\
\hline 210 & $608(76)$ & $458(123)$ \\
\hline 230 & $578(70)$ & $393(47)$ \\
\hline
\end{tabular}

*The values in the parenthesis are standard deviations. / Vrijednosti u zagradama standardne su devijacije. 
Instruments Ltd., Finland). The contact angles were recorded from $1 \mathrm{~s}$ time intervals up to a total of $30 \mathrm{sec}$. Ten specimens were used in the contact angle measurements. A total of 100 measurements, 2 measurements for each specimen, were taken from the equipment.

\section{RESULTS AND DISCUSSION 3. REZULTATI I RASPRAVA}

The surface roughness parameters obtained from the specimens are presented in Figure 2. The untreated control group had the highest surface roughness, while the lowest surface roughness was found in the specimens treated at the highest temperature $\left(230^{\circ} \mathrm{C}\right)$. The average roughness $\left(R_{\mathrm{a}}\right)$ parallel to the fiber direction of the wood was found to be $4.12 \mu \mathrm{m}$ for the untreated control wood, while it was determined as $2.02 \mu \mathrm{m}$ for the wood treated at $230{ }^{\circ} \mathrm{C}$ (Figure 2a). Similar results were found in the $R_{z}$ and $R_{\mathrm{q}}$ values. The surface roughness values parallel to the fiber direction of the wood were found to lower than the roughness values perpendicular to the fiber direction (Figure 2b). The results showed that the heat-treatment and then surface densification greatly improved the surface roughness of wood specimens. The improvement in the surface smoothness of heat-treated spruce wood can also be related to this additional surface densification on the face of the wood. The surface densified wood specimens showed a glossy and smooth appearance after surface densification. Heat-treatment in the vacuum dryer, followed by densification in the hot press, tends to soften the wood fibers close to the surface layers and also plays a part in wood surface compaction and plasticization, which improves the surface smoothness as compared to undensified control wood (Ayrilmis and Winandy, 2009). The severity of the thermal degradation was directly related to the extent of the darkening of the wood color as
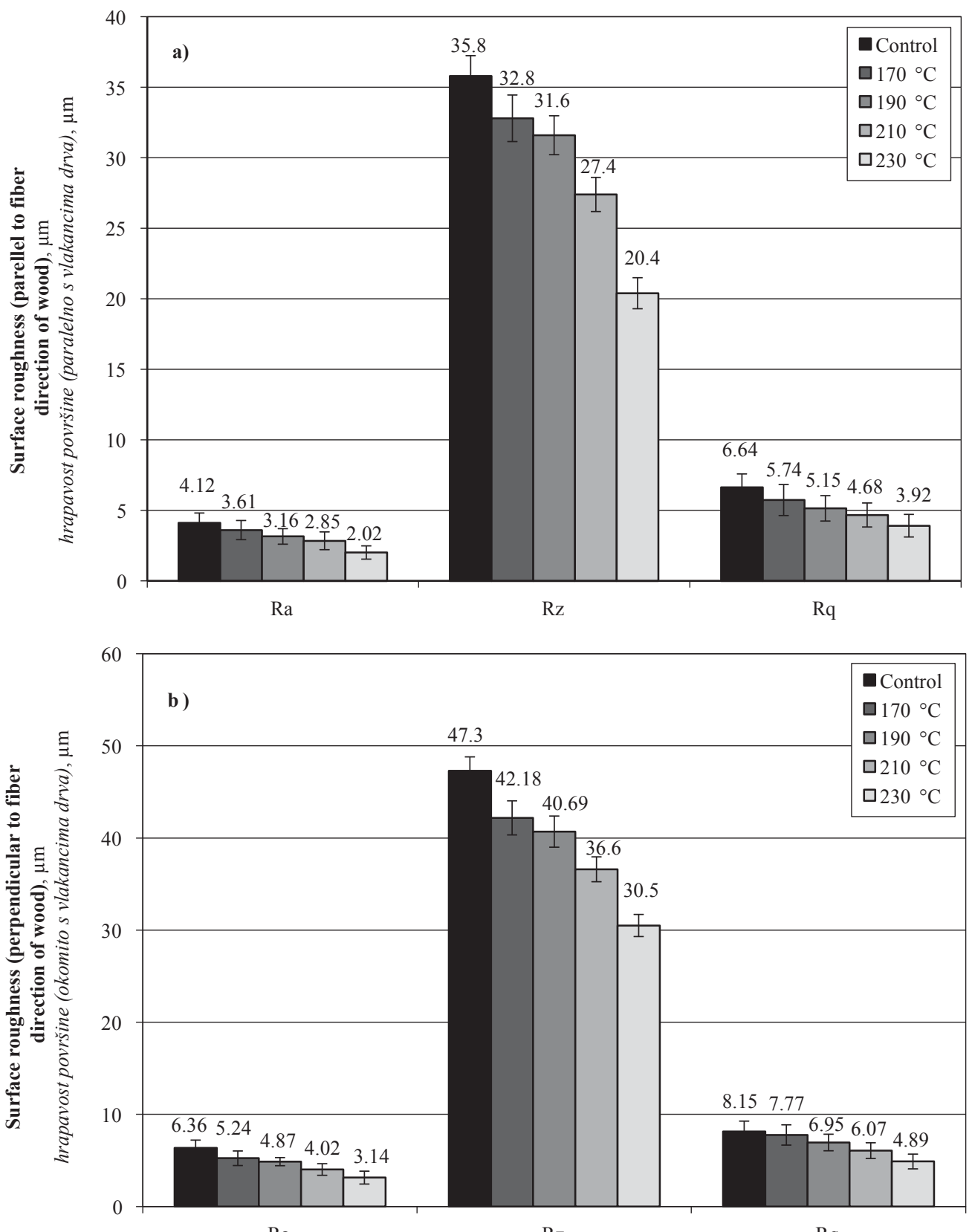

$\mathrm{Ra}$

$\mathrm{Rz}$

$\mathrm{Rq}$

Figure 2 Surface roughness of spruce wood specimens: a) parallel to the fiber direction, b) perpendicular to the fiber direction Slika 2. Hrapavost površine uzorka smrekovine: a) paralelno s vlakancima drva, b) okomito na vlakanca drva 


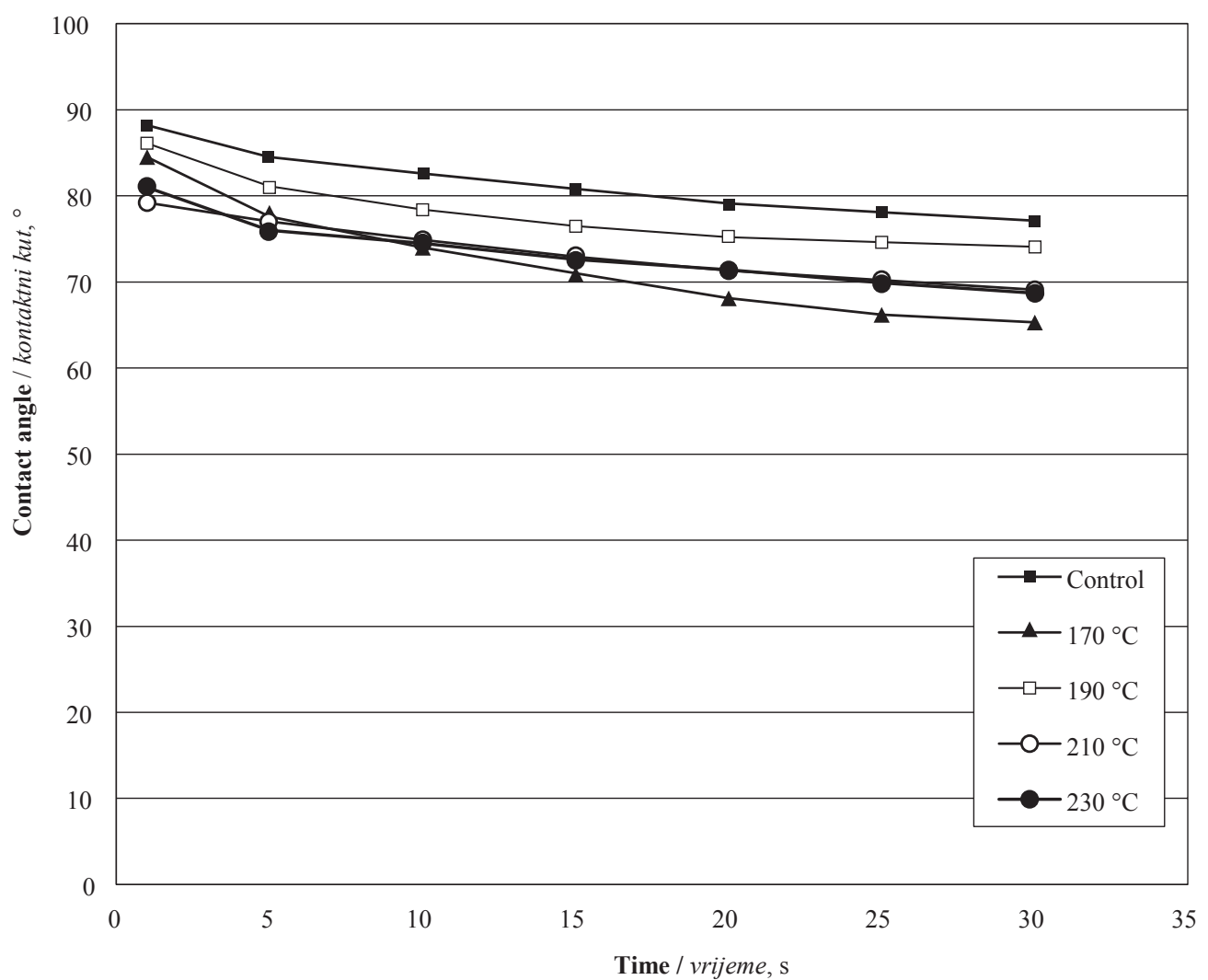

Figure 3 Contact angle values of untreated and treated wood specimens

Slika 3. Vrijednosti kontaktnog kuta netretiranih i tretiranih uzoraka drva

shown in Figure 1. Heat-treated wood specimens had lower equilibrium moisture content than untreated wood control group (Table 1).

During heat-treatment, physical and chemical changes occur in layers close to the surface, which results in a modified surface with new characteristics. At the glass transition temperature $\left(160^{\circ} \mathrm{C}\right)$, plastification of lignin starts affecting particularly the hydrophilic properties of wood (Hakkou et al., 2005a; Petrissans et al., 2003). Previous studies reported that surface roughness of heat-treated wood decreased with increasing treatment temperature and time (Unsal and Ayrilmis, 2005; Korkut and Akgul, 2007; Korkut and Guller, 2008). Better surface smoothness of heat-treated wood could also be explained by the surface densification application. Surface densification reduces the porosity of wood and makes a glossy surface, which decreases the roughness of wood surface (Bekhta and Krystofiak, 2016).

The wettability behavior of the specimens is presented in Figure 3. The highest contact angle value at $1 \mathrm{~s}$ was found in the untreated control specimens, while the lowest contact angle was found in the specimens treated at $210^{\circ} \mathrm{C}$ and then exposed to densification. However, as the measurement time was increased to $30 \mathrm{~s}$, the lowest contact angle was found in the specimens treated at $170{ }^{\circ} \mathrm{C}$.

The average contact angles of untreated control group and specimens treated at different time intervals are presented in Figure 3. It can be seen from Figure 3 that the contact angle values of the control group were higher than those of the treated groups.

Although the wettability of the specimens was measured with pure water, it provided information on the spread of the coatings or adhesives on the wood surface. The surface coatings need to wet, flow or penetrate into the cellular structure of wood to make a good bond between the wood and coatings. The results showed that the wettability of the specimens generally increased with increasing the treatment temperature. The pressure applied to the one-side of the specimens in the hot press had also significant effect on the wettability of the specimens. The results showed that the heat-treatment and surface densification enhanced the wettability of spruce wood. In general, the trend was that the contact angles of the water droplet decreased with increasing heat-treatment temperature, except for the $170{ }^{\circ} \mathrm{C}$. Although some previous studies reported that the densification of wood increase the contact angle value of wood (Kutnar et al., 2012; Krystofiak et al., 2014; Bekhta and Krystofiak, 2016), namely lower wettability, in our research an improvement in the wettability was observed. This can be explained by the lower surface roughness of the specimens. In addition, densified surface can be another reason for the lower contact values due to its glossy surface and plasitification.

All the untreated control groups and treated specimens had a lower contact angle than $90^{\circ}$, which showed good wettability. Previous studies reported that the surface of heat-treated wood is less polar and thus repels water, resulting in a lower wettability than in the case of untreated wood (control group) (Petrissans et al., 2003). Previous studies reported that wood surface becomes hydrophobic after heat-treatment, which results in a higher contact angle value than that of untreated wood (Hakkou et al., 2005a; Hakkou et al., 2005b). A similar 
result was found in this study. In the present study, the contact angle values of the surface-modified specimens were found to be higher than those of control specimens (Figure 3). For example, the contact angle value of the control wood at $10 \mathrm{~s}$ was $82.6^{\circ}$, while it was found to be $74.5^{\circ}$ for the densified wood treated at $230^{\circ} \mathrm{C}$.

\section{CONCLUSIONS \\ 4. ZAKLJUČAK}

This study showed that the surface smoothness and wettability of Norway wood considerably improved with increasing heat treatment temperature. The untreated control group had the highest surface roughness and the lowest wettability. In the treatment groups, the optimum treatment temperature on the oneside densified wood specimens was found to be $170^{\circ} \mathrm{C}$ based on the surface roughness and wettability values. Surface densification also greatly decreased the surface roughness of the wood specimens. The surface densified wood specimens showed a glossy and smooth appearance as well as darkening in the color depending on the severity of heat-treatment. The surface quality of low quality wood can be improved by heat treatment followed by surface densification. Apart from traditional heat-treatment process, the application of surface densification to the heat-treated Norway spruce wood improves the surface quality of wood, which is important for liquid and powder coating applications. The surface densification process after the heat treatment may be considered to replace more expensive hardwoods for outdoor applications such as flooring, siding, decking, and wall cladding.

\section{Acknowledgements - Zahvala}

The authors would like to thank Slovenian Research Agency (P4-0015) for financial support.

The authors would also like to thank Jure Žigon for his technical contribution. This study was also supported by Research Fund of Istanbul Univesity-Cerrahpasa. Project number: BYP-2018-31298.

\section{REFERENCES}

\section{LITERATURA}

1. Ayrilmis, N.; Winandy, J. E., 2009: Effects of post heattreatment on surface characteristics and adhesive bonding performance of medium density fiberboard. Materials and Manufacturing Processes, 24: 594-599. https://doi. org/10.1080/10426910902748032.

2. Bekhta, P.; Krystofiak, T., 2016: The influence of shortterm thermo-mechanical densification on the surface wettability of wood veneers. Maderas Ciencia y Tecnología, 18 (1): 79-90. http://dx.doi.org/10.4067/S0718221X2016005000008

3. Govorčin, S.; Sinković, T.; Hrčka, R., 2009: Some physical and mechanical properties of recent and heat treated ash Fraxinus excelsior L. Drvna industrija, 133: 185-191.

4. Hakkou, M.; Petrissans, M.; Zoulalian, A.; Gerardin, P., 2005a: Investigation of wood wettability changes during heat-treatment on the basis of chemical analysis. Polymer Degradation and Stability, 89: 1-5.

https://doi.org/10.1016/j.polymdegradstab.2004.10.017.

5. Hakkou, M.; Petrissans, M.; El Bakali, I.; Gerardin, P.; Zoulalian, A., 2005b: Wettability changes and mass loss during heat-treatment of wood. Holzforschung, 59: 3537. https://doi.org/10.1515/HF.2005.006.

6. Hill, C. A. S., 2006: Wood Modification: Chemical, Thermal and Other Processes. John Wiley \& Sons, Ltd., Bongor.

7. Kajita, H.; Skaar, C., 1992: Wettability of the surfaces of some American softwoods species. Mokuzai Gakkaishi, 38: 516-521.

8. Kariz, M.; Kuzman, M. K.; Sernek, M.; Hughes, M.; Rautkari, L.; Kamke, F. A.; Kutnar, A., 2017: Influence of temperature of thermal treatment on surface densification of spruce. European Journal of Wood and Wood Products, 75: 113-123. https://doi.org/10.1007/s00107-016-1052-z.

9. Korkut, S.; Akgul, M., 2007: Effect of drying temperature on surface roughness of oak (Quercus petraea ssp. iberica (Steven ex Bieb) Krassiln) Veneer. Building and Environment, 42: 1931-1935. https://doi.org/10.1016/j. buildenv.2006.04.010.

10. Korkut, D. S.; Guller, B., 2008: The effects of heat-treatment on physical properties and surface roughness of red-bud maple (Acer trautvetteri Medw.) wood. Bioresource Technology, 99: 2846-2851. https://doi.org/10.1016/j.biortech.2007.06.043.

11. Krystofiak, T.; Bekhta, P.; Muszyńska, M., 2014: Effect of temperature of thermo-mechanical treatment of pine wood (Pinus sylvestris L.) veneers upon gloss and wettability. Annals of Warsaw University of Life Sciences SGGW Forestry and Wood Technology, 88: 126-129.

12. Kutnar, A.; Laine, K.; Hughes, M., 2012: Thermodynamic characteristics of surface densified solid Scots pine wood. Holz als Roh und Werkstoff, 70: 727-734. https:// doi.org/10.1007/s00107-012-0609-8.

13. Kwon, J. H.; Shin, R. H.; Ayrilmis, N.; Han, T. H., 2014: Properties of solid wood and laminated wood lumber manufactured by cold pressing and heat treatment. Materials and Design, 62: 375-381. https://doi.org/10.1016/j. matdes.2014.05.032.

14. Lunguleasa, A.; Ayrilmis, N.; Spirchez, C.; Özdemir, F., 2018: Investigation of the effects of heat treatment applied to beech plywood. Drvna industrija, 69: 349-355. https://doi.org/10.5552/drind.2018.1768.

15. Petrissans, M.; Gerardin, P.; Elbakali, D.; Serraj, M., 2003: Wettability of heat-treated wood. Holzforschung, 57: 301-307. https://doi.org/10.1515/HF.2003.045.

16. Sinković, T.; Govorčin, S.; Sedlar, T., 2011: Comparison of physical properties of untreated and heat treated beech and hornbeam. Drvna industrija, 62: 283-290. https://doi. org/10.5552/drind.2011.1118

17. Tjeerdsma, B. F.; Boonstra, M.; Militz, H., 1998: Thermal modification of nondurable wood species. Part 2. Improved wood properties of thermally treated wood. International Research Group on Wood Preservation, IRG/WP 98-40124, p 12.

18. Unsal, O.; Ayrilmis, N., 2005: Variations in compression strength and surface roughness of heat-treated Turkish river red gum (Eucalyptus camaldulensis) wood. Journal of Wood Science, 51: 405-409. https://doi.org/10.1007/ s10086-004-0655-x.

19. ***ISO 4287, $1997+$ Amd.1, 2009: Geometrical product specifications (GPS). Surface texture. Profile method. Terms. Definitions and surface texture parameters.

\section{Corresponding address:}

\section{Assoc. Prof. MANJA KITEK KUZMAN, PhD}

University of Ljubljana

Biotechnical Faculty

Department of Wood Science and Technology

Jamnikarjeva 101, SI-1000 Ljubljana, SLOVENIA

e-mail: manja.kuzman@bf.uni-lj.si 